\title{
Management of Gestational Diabetes Mellitus: Self- efficacy and Perinatal Outcomes
} \section{Gestasyonel Diyabetes Mellitus Yönetimi: Öz-etkililik ve Perinatal Sonuçlar}

\author{
Emine Gerçek, Hakan Şen* \\ Adnan Menderes University Söke Faculty of Health Sciences, Department of Nursing, Aydın, Turkey \\ *Söke Fehime Faik Kocagöz State Hospital, Clinic of Child Health and Diseases, Aydın, Turkey
}

Keywords

Gestational diabetes, self-efficacy, perinatal outcomes

\author{
Anahtar kelimeler \\ Gestasyonel diyabet, öz-etkililik, perinatal \\ sonuçlar
}

Received/Geliş Tarihi : 26.05.2014

Accepted/Kabul Tarihi : 17.02.2015

DOI: $10.4274 /$ jcp. 44366

Address for Correspondence/Yazışma Adresi: Emine Gerçek MD, Adnan Menderes University Söke Faculty of Health Sciences, Department of Nursing, Aydın, Turkey

Phone: +90 5325999132

E-mail: emine.gercek@gmail.com

(c) The Journal of Current Pediatrics, published by Galenos Publishing. (c) Güncel Pediatri Dergisi, Galenos Yayınevi tarafından basılmıștır.

\begin{abstract}
The purpose of this review is to give knowledge about effects on perinatal outcomes of self-efficacy in management of gestational diabetes. Gestational diabetes mellitus (GDM) is a significant health concern due to the potentially adverse outcomes for the mother and the fetus/infant. Close monitoring and treatment of GDM are important to the long-term health of a pregnant woman and her baby. More over, maternal metabolic control during pregnancy may positively impact women's risk of later onset of type II diabetes and the risk of obesity and type II diabetes in their children. There are few studies which focus on selfefficacy and adoption of health behaviors in women with GDM; however, there is strong evidence demonstrating that health promotion behavior such as weight loss, exercise, healthy diet and self-monitoring blood glucose concentrations will decrease the risk of developing diabetes mellitus (DM). In addition, lifestyle modifications (e.g. weight loss, healthy diet, and exercise), compliance with physician appointments, and postpartum glucose screening are essential for early diagnosis and prevention of DM in women with GDM.
\end{abstract}

\section{$\ddot{O} z$}

$\mathrm{Bu}$ derlemenin amacı gestasyonel diyabetin yönetiminde öz-etkililiğin perinatal sonuçlar üzerindeki etkisi hakkında bilgi vermektir. Gestasyonel diyabetes mellitus (GDM) anne ve fetüs/yenidoğan sağlığı açısından potansiyel olumsuz sonuçları nedeniyle önemli bir sağlık problemidir. GDM'nin tedavisi ve yakın monitörizasyon gebe kadın ve bebeğinin uzun dönem sağlı̆̆ı için önemlidir. Dahası gebelikte maternal metabolik kontrol, kadınlarda tip II diyabet gelişme riskinin geciktirmenin yanısıra çocuklarda da obezite ve tip II diyabet gelişme riskini geciktirmektedir. GDM'li kadınlarda öz-etkililik ve sağlık davranışlarını benimseme konusunda birkaç çalışma bulunmaktadır. Bununla birlikte, kilo kaybı, egzersiz, diyet ve kendi kendine kan glukozu kontrolü gibi sağlığ 1 geliştirme davranışlarının diyabet gelişme riskini azalttı̆̆ını gösteren güçlü kanıtlar vardır. Gestasyonel diyabetli kadınlarda diyabetin erken tanısı ve önlenmesinde yaşam biçimi değişiklikleri (kilo kaybı, egzersiz, diyet vb.), hekim izlemi ve postpartum glukoz taraması gereklidir.

\section{Introduction}

Gestational diabetes mellitus (GDM) represents a failure to maintain normal glucose tolerance during extreme metabolic stress of pregnancy (1). This disease, defined as any degrees of glucose intolerance first appearing or recognized during pregnancy, is potentially hazardous to 
both the mother and the fetus (2). GDM is one of the most common complications of pregnancy (1). It is estimateed that GDM affects 1-14\% of all pregnancies $(2,3)$. Worldwide, the incidence of GDM is increasing and its increasing prevalence is related to a range of factors including advanced maternal age, obesity and migratory patterns (3). Each year, this disorder affects approximately $4-10 \%$ of pregnant women in the United States (4). In Australia it is estimated that the GDM rate is between $5.2 \%$ and $8.8 \%$ (5). However, few studies about GDM have been performed in our country and the prevalence of GDM in these studies was found to be between $1.23 \%$ and $9.2 \%$ (6-11). Once GDM is diagnosed, it is likely to recur in 35$50 \%$ of future pregnancies and the risk of developing type II diabetes will increase by $40-60 \%$ within 10 years. Similarly, children of these women also have an elevated risk of developing obesity and diabetes in their lifetime (12). Thus, there is an important need for an excellent treatment and preferably prevention strategies for GDM. Moreover, maternal metabolic control during pregnancy may positively impact women's risk of later onset of type II diabetes and the risk of obesity and type II diabetes in their children, making prevention or treatment of GDM additionally important (13).

\section{Self-efficacy}

Self-efficacy is an individual's belief that he/she is capable of performing specific tasks to obtain certain goals and is a strong predictor of health behavior (14). Individuals with high self-efficacy are more likely to set goals, stay committed to those goals and work harder to achieve the goals. Therefore, they are more likely to make a change in their behavior and adhere to that behavior over a long period of time, thus leading to better health outcomes (15). In contrast, people with low self-efficacy will experience poor outcomes, have low aspirations and little commitment to achieve goals, and give up if tasks become difficult. Health promoting behavior is influenced by one's belief in his/her ability to appropriately perform an activity; thus, engagement and maintenance of health behavior will more likely occur in individuals with stronger self-efficacy (16). The goal of behavioral intervention is to influence psychosocial mediators of health behavior in order to achieve desired behavioral changes. Several behavioral theories, particularly the theory of reasoned action and planned behavior and social cognitive theory, posit that confidence to perform a task (otherwise known as self-efficacy) and the available social support for that task can be key mediators and moderators of lifestyle behavior. For example, in the Diabetes Prevention Programme, self-efficacy for physical activity was associated with greater performance of physical activity, and selfefficacy for not overeating was associated with lower baseline body mass index (BMI) (17-20).

The initial treatment for GDM remains to be diet and exercise. Generally, a 1900 to $2400 \mathrm{kcal} / \mathrm{d}$ diet with carbohydrate restriction to $35 \%$ to $40 \%$ of calories is prescribed, based on ideal prepregnancy body weight and using complex and high-fiber carbohydrates (21). The assistance of a trained dietician is ideal for tailoring dietary needs for each woman. Dietary therapy delays pharmacologic therapy. Moses et al. (12) using a low-glycemic diet as treatment for GDM and in a prospective fashion showed that a low-glycemic diet decreased the need and timing for insulin. Most women lose weight during initial weeks of dietary therapy, but then resume modest weight gain. Insufficient dietary calories can be judged by excessive hunger, excessive weight loss, or persistent ketonuria. If exercise is not contraindicated for other obstetric complications of pregnancy, it can improve glycemic control in any type of diabetes. Women with GDM should be asked to walk 1 to 2 miles at least 3 times a week if possible (22).

Many women have the misconception that GDM only affects them during pregnancy, and that once the baby is delivered, the complication is no longer a health problem (23). In fact, long term consequences of obesity and risk of diabetes mellitus (DM) are significant. There is strong evidence demonstrating that health promotion behavior such as weight loss, exercise, healthy diet and self monitoring blood glucose (SMBG) will decrease the risk of developing DM (24). In addition, lifestyle modifications (e.g. weight loss, healthy diet, and exercise), compliance with physician appointments and postpartum glucose screening are essential for early diagnosis and prevention of DM in women with GDM (25). Numerous research studies in the general population have shown that adoption of healthy lifestyles (e.g. healthy diet, exercise, weight loss) can prevent DM; however, there is limited 
research which focuses on healthy lifestyle behavior in women with GDM. There is a limited number of studies which focus on self-efficacy and adoption of health behavior in women with GDM. In Amason (26) study, self-efficacy was the only significant predictor for adopting healthy lifestyle behavior in pregnant women with GDM. Kim et al. (27), revealed that a group of well-educated white women with GDM who had low self-efficacy scores also had low physical activity, unhealthy diets, and higher BMI. In comparison, Koh et al. (28) performed a cross-sectional telephone survey on women with a recent history of GDM to determine physical activity and psychosocial factors associated with engagement in health activity. Women with higher social support (support from significant others or family members) and self-efficacy were more likely to be engaged in physical activity, although the study determined a low prevalence of physical activity in general. In a study by Homko et al. (29) differences in feelings of self-efficacy over time between a SMBG group and a periodic monitoring (PM) group were assessed by comparing their delta scores on the Diabetes Empowerment Scale. No significant differences in the delta scores were found between the two groups. However, it was postulated that successful mastery of SMBG would enhance women's feeling of self-efficacy, thereby improving adherence to the diabetes self-care management regimen and ultimately improving metabolic control as well as maternal and neonatal outcomes. However, the women in the SMBG and PM groups had similar rates of macrosomia, birth trauma, infant birth rates and neonatal morbidities. In a study performed by Kim and Kim (30) to assess effects of an integrated self-management program on self-management, glycemic control, and maternal identity in women with GDM, there were statistically significant increases in self-management and maternal identity, and decreases in 2-h postprandial glucose levels in the experimental group compared to the control group. In a study related to use of an internetbased telemedicine system to manage underserved women with gestational DM, there was not a difference between the internet and control groups regarding either fasting or postprandial blood glucose values and pregnancy and neonatal outcomes. It was found out that that women in the internet group demonstrated significantly higher feelings of self-efficacy at the end of the study (31).
Close monitoring and treatment of GDM are important to the long-term health of a pregnant woman and her baby. The fifth International Workshop Conference on Gestational Diabetes recommended the following blood glucose concentrations; fasting plasma glucose of 90 to $99 \mathrm{mg} / \mathrm{dL}(5.0-5.5 \mathrm{mmol} / \mathrm{L})$, 1-hour postprandial plasma glucose less than $140 \mathrm{mg} / \mathrm{dL}(<7.8 \mathrm{mmol} / \mathrm{L})$ and 2-hour postprandial plasma glucose less than 120 to $127 \mathrm{mg} / \mathrm{dL}$ ( $<6.7-7.1 \mathrm{mmol} / \mathrm{L})$. Baseline and interval hemoglobin A1c levels during treatment are helpful, particularly in women who have fasting hyperglycemia (32). Most women with GDM on diet treatment alone monitor capillary blood glucose levels 4 times a day (fasting blood glucose once a day and postprandial blood glucose thrice a day); women on pharmaceutical therapy often monitor blood glucose levels 4 to 6 times a day, including preprandial values. Weekly inoffice monitoring and daily self-monitoring seem to have comparable outcomes in perinatal mortality and morbidity (33). However, Hawkins et al. (34) suggested that women with daily, more frequent monitoring may have less macrosomia. According to results of a study by Symons Downs (35) women with GDM believed that controlling blood glucose was the most important advantage of exercising during their pregnancy and that postpartum exercising controlled their weight.

\section{Perinatal Outcomes}

Gestational diabetes is a significant health concern due to its potentially adverse outcomes for the mother and the fetus/infant. Maternal complications due to gestational diabetes include hypoglycemia, increased risk of preeclampsia, infection, and conversion to type II diabetes following pregnancy (36). The risk of recurrence of gestational diabetes in a subsequent pregnancy is $35.6 \%$ and is predicted by maternal weight at subsequent pregnancy and infant birth-weight during prior pregnancy accompanied by gestational diabetes (37). Compared to babies of women in a normal weight range, babies of overweight and obese women are more likely to be macrosomic (38) and preterm have a congenital anomaly, are admitted to the neonatal intensive care unit (NICU) and need treatment for jaundice or hypoglycaemia (39). Thus, GDM particularly in overweight and obese women increases both short and long term risks to the health of both the woman and her baby. 
Macrosomia is associated with pregnancies complicated by poorly controlled diabetes and macrosomia, itself, has been associated with childhood obesity (40). Tyrala (41) cited a $26 \%$ rate of macrosomic births to women with diabetes. A study conducted by Tanır et al. (42) to elucidate maternal complications and perinatal morbidity and mortality in a 10-year retrospective cohort of GDM cases showed fetal macrosomia in $18(25.7 \%)$ pregnancies. The study also revealed that vacuum extraction and forceps applications were indicated in 10\% of all GDM groups and that the fetuses born to women having cesarean section were heavier at birth compared to those of women having vaginal births.

The recent Hyperglycemia and Adverse Pregnancy Outcome study found a continuous association between maternal glucose concentrations and increasing birth weight, umbilical cord C-peptide levels, and neonatal adiposity (43). Although the link between increasing maternal glucose and such neonatal outcomes has been established, whether it is the fasting or postprandial blood glucose levels that correlate better with such markers of adiposity is uncertain. Previous studies have suggested that postprandial blood glucose levels are more predictive than fasting glucose for neonatal outcomes such as macrosomia and hypoglycemia (44). Uvena-Celebrezze et al. (45) in a recent study on 18 women with gestational diabetes, of whom $50 \%$ were treated with insulin, revealed that fasting glucose correlated most with fetal fat mass.

The relationship between fasting and postprandial glucose levels as well as the length of nutrition intervention and neonatal outcomes in women diagnosed with mild gestational diabetes is unknown. Detection of such a relationship can aid in establishing blood glucose targets when treating women with glucose intolerance during pregnancy. Durnwald et al. (46) found that median fasting glucose concentrations during initiation of dietary treatment for mild gestational diabetes are associated with elevated umbilical cord C-peptide levels and increased neonatal fat mass. Furthermore, median fasting glucose two weeks before delivery was also associated with being large for gestational age (LGA) and macrosomia.

In the third trimester, maternal glycemia appears to influence fetal growth. Some authors speculate that in the second trimester and in the early third trimester fetal growth is determined largely by genetics and maternal obesity, which enhance fetal adipose deposition. Maternal BMI and a previous LGA baby were the strongest predictors of increased fetal growth (47). The intrauterine environment during a pregnancy complicated by gestational diabetes has been examined for its role in laying a foundation for childhood metabolic syndrome, and later development of diabetes. Boney et al. (48) found a 50\% risk for childhood metabolic syndrome in infants of diabetic mothers who had birth macrosomia. An association between intrauterine exposure to hyperglycemia and later onset of gestational diabetes in a female infant has been demonstrated (49).

Women with GDM and their infants are at risk for short term and long term consequences of the disease. Cesarean section rates are high in women with GDM due to cephalopelvic disproportion and macrosomia (50). The newborn has an increased risk of shoulder dystocia, birth injury, or death during a vaginal delivery (51). Other associated complications in the newborn include hypoglycemia, respiratory distress syndrome, hyperbilirubinemia, and an increased need for advanced medical care in the NICU $(52,53)$.

In Tomić et al. (52) study, a LGA newborn, staying in the NICU $>24 \mathrm{~h}$, neonatal hyperbilirubinemia and cesarean section due to cephalopelvic disproportion were identified as specific adverse outcomes of GDM. Tanır et al. (42) in their study on a ten-year GDM cohort including 110 diabetic pregnancies found that the most frequent neonatal morbidity was hyperbilirubinemia in $25(35.7 \%)$ newborns.

Wang et al. (53) in their review of 25 studies revealed that the most commonly reported outcomes were cesarean delivery, macrosomia and stillbirth. Cesarean delivery had the highest median incidence at $43.8 \%$ (interquartile range, 34.9\%-65.9\%). A newborn LGA, jaundice and macrosomia had median incidences of $17 \%$ or greater. Postpartum hemorrhage $(0.8 \%)$ and shoulder dystocia $(1.4 \%)$ were the two adverse outcomes with the lowest median incidences in mothers and infants respectively.

The Hyperglycemia and Adverse Pregnancy Outcome study showed that four primary outcomes of intrauterine hyperglycemia (macrosomia, cesarean delivery, neonatal hypoglycemia, and neonatal hyperinsulinemia) were significantly higher in women with higher maternal glucose levels (e.g. fasting $>100$ $\mathrm{mg} / \mathrm{dl}$ ) (37). This epidemiological study, performed 
in nine countries, yielded strong evidence about the importance of glucose control during pregnancy and possible redefining thresholds for diagnosis of GDM (54).

In a follow-up study [Clausen et al. (55), 2008] carried out to determine glucose tolerance in 597 adults aged 18-27 years who were offspring of women with GDM or type I diabetes, approximately $20 \%$ of the children with a mother who had GDM had DM/ pre-diabetes. In comparison to the general population, an offspring born to a mother with GDM had an eight fold increased risk of diabetes and/or pre-diabetes (55), suggesting that glucose control during pregnancy is essential for the health of children born to mothers with GDM. Kim et al. (56) examined the association between risk perception, current behaviour (dietary habits and physical activity), intentions to change this behaviour, and recent changes in behaviour among women with GDM. Their results showed that only $16 \%$ of women believed that they were at high risk of developing type II diabetes although $90 \%$ agreed that GDM was a risk factor for future onset of this type of metabolic disorder.

\section{Conclusions}

Numerous intervention studies on the general population have demonstrated that adoption of healthy lifestyle behavior (e.g. healthy diet, exercise, weight loss, SMBG) decreases the risk of developing DM, but limited research has explored strategies to encourage women with a diagnosis of GDM to implement that behavior during pregnancy, postpartum period and throughout their lifetime. A significant finding revealed in this article is that when a woman has the confidence in her ability to change her own behavior, she is more likely to engage in healthy lifestyle behavior.

It has been suggested that once individuals at risk of diabetes are identified, they should be counseled by health care providers. In fact, women with GDM should be provided with information on the long term effects of GDM and DM preventative care including diet, exercise, weight reduction and SMBG (57).

The focus of researchers should be on different strategies for delivery of education and counseling for women with GDM. Interventions should be offered at one to one counseling sessions or development of other creative strategies, such as the use of technology, can be useful for many women who have difficulty adhering to appointment schedules. Future research for preventive care of women with GDM needs to focus on prevention programs established for the needs and challenges of adoption of healthy lifestyles in pregnant and postpartum women. Prospective longitudinal studies that review effects of educational interventions during prenatal or postpartum periods and effects on health behavior of women with GDM are needed.

\section{Ethics}

Peer-review: Externally peer-reviewed.

\section{Authorship Contributions}

Surgical and Medical Practices: Emine Gerçek, Hakan Şen, Concept: Emine Gerçek, Design: Emine Gerçek, Hakan Şen, Data Collection or Processing: Emine Gerçek, Hakan Şen, Analysis or Interpretation: Emine Gerçek, Literature Search: Emine Gerçek, Hakan Şen, Writing: Emine Gerçek.

Conflict of Interest: The authors declared no potential conflicts of interest with respect to the research, authorship, and/or publication of this article.

Financial Disclosure: No financial support was provided for our study by any sponsoring organization or any for-profit product companies.

\section{References}

1. Kjos SL, Buchanan TA. Gestational diabetes mellitus. N Engl J Med 1999;341:1749-56.

2. American Diabetes Association: Gestational diabetes mellitus. Diabetes Care 2004;27:588-90.

3. Ferrara A. Increasing prevalence of gestational diabetes mellitus: A public health perspective. Diabetes Care 2007;30(Suppl 2):141-6.

4. American Diabetes Association. Gestational diabetes mellitus (position statement) Diabetes Care 2009;27:88-90.

5. Cheung NW, Byth K. Population health significance of gestational diabetes. Diabetes Care 2003;26:2005-9.

6. Erem C, Cihanyurdu N, Deger O, Karahan C, Can G, Telatar M. Screening for gestational diabetes mellitus in northeastern Turkey (Trabzon city). Eur J Epidemiol 2003;18:39-43.

7. Akış N,Pala K, Seçkin RÇ. The prevalence of gestational diabetes mellitus and associated risk factors. Uludağ Med J 2008;34:93-6.

8. Batukan C, Gürel C, Özgün MT, Başbuğ M. Prevalence of gestational diabetes among pregnant women attending Erciyes University Medical Faculty. Erciyes Med J 2009;31:323-30.

9. Akbay E, Torun S İ, Yalçınkaya H, Uzunçakmak C, Toklucu G. Prevalence of gestational diabetes among pregnant women attending in MD Sadi Konuk training and research hospital. Turkiye Klinikleri J Gynecol Obst 2010;20:170-5. 
10. Turgut A, Boran SÜ, Dolgun ZN, Acıoğlu H, Görük NY. The frequency of gestational diabetes mellitus in a maternity hospital antepartum clinic. Dicle Med J 2011;38:325-28.

11. Özyurt R, Aşıcıoğlu O, Gültekin T, Güngördük T, Boran B. The prevalence of gestational diabetes mellitus in pregnant women who were admitted to İstanbul Teaching and Research Hospital Obstetric and Gynecology Department. JOPP Derg 2013;5:712.

12. Moses RG, Barker M, Winter M, Petozc P, Brand-Miller JC. Can a low-glycemic index diet reduce the need for insulin in gestational diabetes mellitus? A randomized trial. Diabetes Care 2009;32:996-1000.

13. Fletcher B, Gulanick M, Lamendola C. Risk factors for type 2 diabetes mellitus. J Cardiovasc Nurs 2002;16:17-23.

14. Bandura A. Self-efficacy. Encyclopedia of Human. Behavior 1994;4:71-81.

15. Rosenstock IM, Strecher VJ, Becker MH. Social learning theory and health belief model. Health Educ Q 1988;11:403-18.

16. Bandura A. Health promotion by social cognitive means. Health Educ Behav 2004;31:143-64.

17. Lee AJ, Hiscock RJ, Wein P, Walker SP, Permezel M. Gestational diabetes mellitus: Clinical predictors and long-term risk of developing type 2 diabetes: A retrospective cohort study using survival analysis. Diabetes Care 2007;30:878-83.

18. Reece EA, Leguizamon G, Wiznitzer A. Gestational diabetes: The need for a common ground. Lancet 2009;373:1789-97.

19. Bauman A, Sallis J, Dzewaltowski DA, Owen N. Toward a better understanding of the influences on physical activity: The role of determinants, correlates, causal variables, mediators, moderators, and confounders. Am J Prev Med 2002;23(Suppl 2):5-14.

20. Delhanty LM, Conroy MB, Nathan DM: Diabetes Prevention Program Research Group. Psychological predictors of physical activity in the diabetes prevention program. J Am Diet Assoc 2006;106:698-705.

21. American Diabetes Association. Evidence-based nutrition principles and recommendations for the treatment and prevention of diabetes and related complications. Diabetes Care 2003;26:5161.

22. Smith BJ, Cheung NW, Bauman AE, Zehle K, McLean M. Postpartum physical activity and related psychosocial factors among women with recent gestational diabetes mellitus. Diabetes Care 2005;28:2650-54.

23. Kim C, McEwen LN, Piette JD, Goewey J, Ferrara A, Walker EA. Risk perception for diabetes among women with histories of gestational diabetes mellitus. Diabetes Care 2007;30:2281-6.

24. England LJ, Dietz PM, Njoroge T, Callaghan WM, Bruce C, Buus RM, et al. Preventing type 2 diabetes: Public health implications for women with a history of gestational diabetes mellitus. Am J Obstet Gynecol 2009;200:365.

25. Baker A, Brody S, Salisbury K, Schectman R, Hartmann $\mathrm{K}$. Postpartum glucose tolerance screening in women with gestational diabetes in the state of North Carolina. N C Med J 2009;70:14-9.

26. Amason JS. The Effect of an Educational Intervention in Women with Gestational Diabetes: A Pilot Study Georgia State University (Doctoral Dissertation). Atlant; 2013.

27. Kim C, McEwen LN, Kieffer EC, Herman WH, Piette JD. Selfefficacy, social support, and associations with physical activity and body mass index among women with histories of gestational diabetes mellitus. Diabetes Educ 2008;34:719-28.
28. Koh D, Miller YD, Marshall AL, Brown WJ, McIntyre D. Health enhancing physical activity behaviour and related factors in postpartum women with recent gestational diabetes mellitus. J Sci Med Sport 2010;13:42-5.

29. Homko CJ, Sivan E, Reece EA. The impact of self-monitoring of blood glucose on self-efficacy and pregnancy outcomes in women with diet-controlled gestational diabetes. Diabetes Educ 2002;28:435-43.

30. Kim H, Kim S. Effects of an integrated self-management program on self-management, glycemic control, and maternal identity in women with gestational diabetes mellitus. J Korean Acad Nurs 2013;43:69-80.

31. Homko CJ, Santamore WP, Whiteman V, Bower M, Berger P, Geifman-Holtzman O, et al. Use of an internet-based telemedicine system to manage underserved women with gestational diabetes mellitus. Diabetes Technol Ther 2007;9:297-306.

32. Metzger BE, Buchanan TA, Coustan DR, de Leiva A, Dunger DB, Hadden DR, et al. Summary and recommendations of the Fifth International Workshop-Conference on Gestational Diabetes Mellitus. Diabetes Care 2007;30:251-60.

33. Pridjian G, Benjamin TD. Update on gestational diabetes. Obstet Gynecol Clin North Am 2010;37:255-67.

34. Hawkins JS, Casey BM, Lo JY, Moss K, Mc Intire DD, Leveno KJ. Weekly compared with daily blood glucose monitoring in women with diet-treated gestational diabetes. Obstet Gynecol 2009;113:1307-12.

35. Symons Downs D, Ulbrecht JS. Understanding exercise beliefs and behaviors in women with gestational diabetes mellitus. Diabetes Care 2006;29:236-40.

36. Catalano PM, Kirwan JP, Haugel-de Mouzon S, King J. Gestational diabetes and insulin resistance: Role in short and longterm implications for mother and fetus. J Nutr 2003;133(Suppl 2):1674-83.

37. MacNeill S, Dodds L, Hamilton DC, Armson BA, VandenHof $\mathrm{M}$. Rates and risk factors for recurrence of gestational diabetes. Diabetes Care 2001;24:659-62.

38. Dodd JM, Grivell RM, Nguyen A-M, Chan A, Robinson JS. Maternal and perinatal health outcomes by body mass index category. Aust N Z J Obstet Gynaecol 2011;51:136-40.

39. Galtier-Dereure F, Boegner C, Bringer J. Obesity and pregnancy: Complications and cost. Am J Clin Nutr 2000;71(Suppl 5):12428.

40. Boulet S, Alexander GR, Salihu HM, Pass M. Macrosomic births in the united states: Determinants, outcomes, and proposed grades of risk. Am J Obstet Gynecol 2003;188:1372-8.

41. Tyrala EE. The infant of the diabetic mother. Obstet Gynecol Clin North Am 1996;23:221-41.

42. Tanır HM, Sener T, Gürer H, Kaya M. A ten-year gestational diabetes mellitus cohort at a university clinic of the mid-Anatolian region of Turkey. Clin Exp Obstet Gynecol 2005;32:241-4.

43. HAPO Study Cooperative Research Group, Metzger BE, Lowe LP, Dyer AR, Trimble ER, Chaovarindr U, et al. Hyperglycemia and adverse pregnancy outcomes. N Engl J Med 2008;358:19912002.

44. Jovanovic-Peterson L, Peterson CM, Reed GF, Metzger BE, Mills JL, Knopp RH, et al. Maternal postprandial glucose levels and infant birth weight: The diabetes in early pregnancy study. The National Institute of Child Health and Human DevelopmentDiabetes in Early Pregnancy Study. Am J Obstet Gynecol 1991;164:103-11. 
45. Uvena-Celebrezze J,Fung C, Thomas AJ,Hoty A,Huston-Presley L, Amini SB, et al. Relationship of neonatal body composition to maternal glucose control in women with gestational diabetes mellitus. J Matern Fetal Neonat Med 2002;12:396-401.

46. Durnwald CP, Mele L, Spong CY, Ramin SM, Varner MW, Rouse DJ, et al. Glycemic characteristics and neonatal outcomes of women treated for mild gestational diabetes. Obstet Gynecol 2011;117:819-27.

47. Schaefer-Graf UM, Kjos SL, Kilavuz O, Plagemann A, Brauer $\mathrm{M}$, Dudenhausen JW, et al. Determinants of fetal growth at different periods of pregnancies complicated by gestational diabetes mellitus or impaired glucose tolerance. Diabetes Care 2003;26:193-8.

48. Boney CM, Verma A, Tucker R, Vohr BR. Metabolic syndrome in childhood: Association with birth weight, maternal obesity, and gestational diabetes mellitus. Pediatrics 2005;115:290-6.

49. McLean M, Chipps D, Cheung NW. Mother to child transmission of diabetes mellitus: Does gestational diabetes program Type 2 diabetes in the next generation? Diabet Med 2006;23:1213-5.

50. Schneiderman EH. Gestational diabetes: an overview of a growing health concern for women. J Infus Nurs 2010;33:48-54.

51. Reece EA. The fetal and maternal consequences of gestational diabetes mellitus. J Matern Fetal Neonatal Med 2010;23:199-203.
52. Tomić V, Petrović O, Crnčević Orlić Ž, Mandić V. Gestational diabetes and pregnancy outcome - do we have right diagnostic criteria? J Matern Fetal Neonatal Med 2013;26:854-9.

53. Wang Z, Kanguru L, Hussein J, Fitzmaurice A, Ritchie K. Incidence of adverse outcomes associated with gestational diabetes mellitus in low- and middle-income countries. Int JGynecol Obstet 2013;121:14-9.

54. Yogev Y, Metzger BE, Hod M. Establishing diagnosis of gestational diabetes mellitus: Impact of the hyperglycemia and adverse pregnancy outcome study. Semin Fetal Neonatal Med 2009;14:94-100.

55. Clausen TD, Mathiesen ER, Hansen T, Pedersen O, Jensen DM, Lauenborg J, et al. High prevalence of type 2 diabetes and pre-diabetes in adult offspring of women with gestational diabetes mellitus or type 1 diabetes: The role of intrauterine hyperglycemia. Diabetes Care 2008;31:340-6.

56. Kim C, McEwen LN, Piette JD, Goewey J, Ferrara A, Walker EA. Risk perception for diabetes among women with histories of gestational diabetes mellitus. Diabetes Care 2007;30:2281-6.

57. Kaiser B, Razurel C. Determinants of postpartum physical activity, dietary habits and weight loss after gestational diabetes mellitus. J Nurs Manag 2013;21:58-69. 